\title{
Heresoi : The Action of Agriculture Land Conservation by Wangi-Wangi Island Community
}

\author{
Hidrawati Hidrawati ${ }^{1}$, Muhamad Aswar Limi ${ }^{2}$, Nur Arafah ${ }^{3}$, \\ Samsul Alam Fyka ${ }^{4}$, Harviyadin Harviyadin ${ }^{5}$ \\ $\left\{\right.$ hidrawati85@yahoo.com ${ }^{1}$, aswar_agribusiness@yahoo.com ${ }^{2}$, noer_arafah@yahoo.com $\left.{ }^{3}\right\}$ \\ 1,2,3,4,5 Halu Oleo University, Indonesia \\ Kampus Hijau Bumi Tridharma, Anduonohu, Kambu, Kendari City, \\ Southeast Sulawesi,Indonesia Post code 93232; Telp. (0401) 3190105; Email: \\ info@unhalu.ac.id
}

\begin{abstract}
This qualitative research are explore heresoi action and assessing economically, socially and ecologically benefits in agricultural land management by Wangi-Wangi Island community. The research was conducted from October 2017 to September 2018 which was located on Wangi-Wangi Island, Southeast Sulawesi, Indonesia. There are 4 village location research, which purposively determined sampling namely Waha Village, Wungka Village, Liya Togo Village and Pada Raya Makmur Village. The research data was collected through literature study methods, observations and interviews with snowball techniques. The result showed that heresoi action was always applied by WangiWangi Island community in agricultural land management because they believe to be able to fertilize the plants. Economically, heresoi action proven to increase food crop sustainable production. Socially, these actions provide benefits to sustainability aspects of coastal and small island community agricultural traditions unique. Ecologically, heresoi action has implications for increasing soil fertility, forest conservation and integrated waste management systems.
\end{abstract}

Keywords: Action, Agriculture, Conservation, and Wangi-Wangi Island

\section{Introduction}

Wangi-Wangi Island is administrative part of Wakatobi Regency in Southeast Sulawesi Province, Indonesia. Wide of Wakatobi approximately $19.200 \mathrm{~km}^{2}$, while consist of land area $\pm 823 \mathrm{~km}^{2}$ or only 3 percent, and sea $\pm 18,377 \mathrm{~km} 2$ or equal to 97 percent of the all Wakatobi regency area [1]. Astronomically, Wakatobi located in south side of mark with lines the equator, northerly long to south, among 5,000-6,250 parallel South (as long as $\pm 160 \mathrm{~km}$ ) and unfold from West easterly among 123,340-124,640 Longitude East (as long as $\pm 120 \mathrm{~km}$ ) [1]. Geographically, the territorial boundaries of Wakatobi Regency are north and east by Banda Sea, south and west by Flores Sea [1].

Wakatobi has four important island with the name of the word acronym "Wakatobi" namely Wangi-wangi, Kaledupa, Tomia and Binongko [2]. The research was carried out on Wangi-Wangi Island which focused on 4 villages, namely Waha Village, Wungka Village, Liya Togo Village and Pada Raya Makmur Village. The four villages were chosen purposively from 41 villages on Wangi-Wangi Island considering of geographical aspects, namely in the relatively coastal area namely Waha Village located in the northern part of Wangi-Wangi Island and Liya Togo Village in the south. The relatively inland section there 
are Wungka Village in the west and Pada Raya Makmur village in the east. In addition determination study location in the four villages was also based on differences and similarities in heresoi activities by local people.

Approximately 60 percent of Wangi-Wangi Island's land is flat [1] and dominated by low vegetation which grows between rocks with the little soil. In the central part of the island, there are no more than 20 percent low hills and mountains. In the mountain basin area, relatively high vegetation grows and plantations. For communities in this study, farming is developed on flat land with limestone parent material types of coral and podsolict soil. In general, these geological formations indicate low soil fertility due to lack of $\mathrm{pH}$ and soil organic matter [3]. For this reason, local farmers carry out heresoi action as a way to manipulate land conditions to increasing sustainable agricultural productivity.

The main objective of this research are explore heresoi action and assessing economically, socially and ecologically benefits in agricultural land management by Wangi-Wangi Island community. Achieving the goals of this research data collect through literature studies, observations and interviews with the snow ball technique. Interviews with 83 farmers with considering the representation of farmer populations in the research location and saturate information. The qualitative study was conducted from October 2017 to September 2018.

\subsection{Heresoi Action by the Wangi-Wangi Island Community}

Etymologically Wanci Language at Wangi-Wangi Island, heresoi derived from the words "reso" which means dirt, garbage or something that is not used anymore. Initially given "he" which shows "action or effort to give" and the suffix " $i$ " which refers to "what will be given". The suffix " $i$ " usually refers to plants that will be given reso. Heresoi means giving dirt or garbage to plants. Reso can be in the form of waste or household waste such as land; sand; small pebbles; litter of garden plants; leftover processed sea products (fish fins, bones and shellfish), leftover processed products from food crops (corn husk and tuber skin ); the harvested canopy around the farm location; termite house; sawdust; eggshell; charcoal and combustion ash.

Heresoi is an act of giving dirt or garbage around the roots of food crops such as cassava (manihotutilissima), corn (zea mays spp), uwi (dioscorea, spp) and various horticultural plants (eggplant, cucumber, kale, tomatoes, chili, long-beans, kidney beans and others). Scientifically, heresoi can be interpreted as an activity of adding organic material around plant roots, and can also be equated with mulching activities. Mulching is an important technique for improving soil microclimate [4]; structure live and improve soil fertility [5]. Improvements in soil micro climate include mulch function to maintain soil moisture [4] and prevent the negative effects of sunlight radiation [4] or high rainfall. In addition, mulch can reduce weed growth around plants so as to minimize the process of nutrient competition from disturbing plants [5]. Another important thing about mulching is its function to increase soil fertility, because of the weathering process of organic materials [5] which is used as mulch.

The type of waste/manure given adjusted plants to availability by farmers; type of plant; and soil type or condition of agricultural land. Food crops such as maize and cassava on land with a small amount of rock are usually heresoi sufficiently with litter of small crops or processed marine products and other agricultural products. Meanwhile, foodcrops grown in a little rocky land can be heresoi with garbage or dirt soil and sand mix taken from outside the farm location. Heresoi action almost all stages of the plant production process, from the process of land clearing, planting, maintenance and harvest. 
In the opening stages of land, heresoi done by separating the results of land clearing (example pruned or felled vegetation and grasses were removed) were collected in one place. The cleaning results sometimesin fuel, and combustion residue in the form of charcoal and ashes mixed with soil or any other plant litter that had rotted and then used as heresoi material plant. Meanwhile, the results of cleaning that is not burned are allowed to decay and later become heresoi ingredients.

At the beginning of planting, when making planting holes, the soil is only given fertilizer in the form of manure (if any) and generally given heresoi material which is transported by farmers with baskets or sacks when going to the farming location. Heresoi materials are usually mixed with soil or small pieces of rock to store seeds planted. If there is not enough material heresoi soil, farmers sometimes use only small pieces of rock or gravel to stockpile seeds planted. The sample heresoi process can be seen in figura1 as follows:
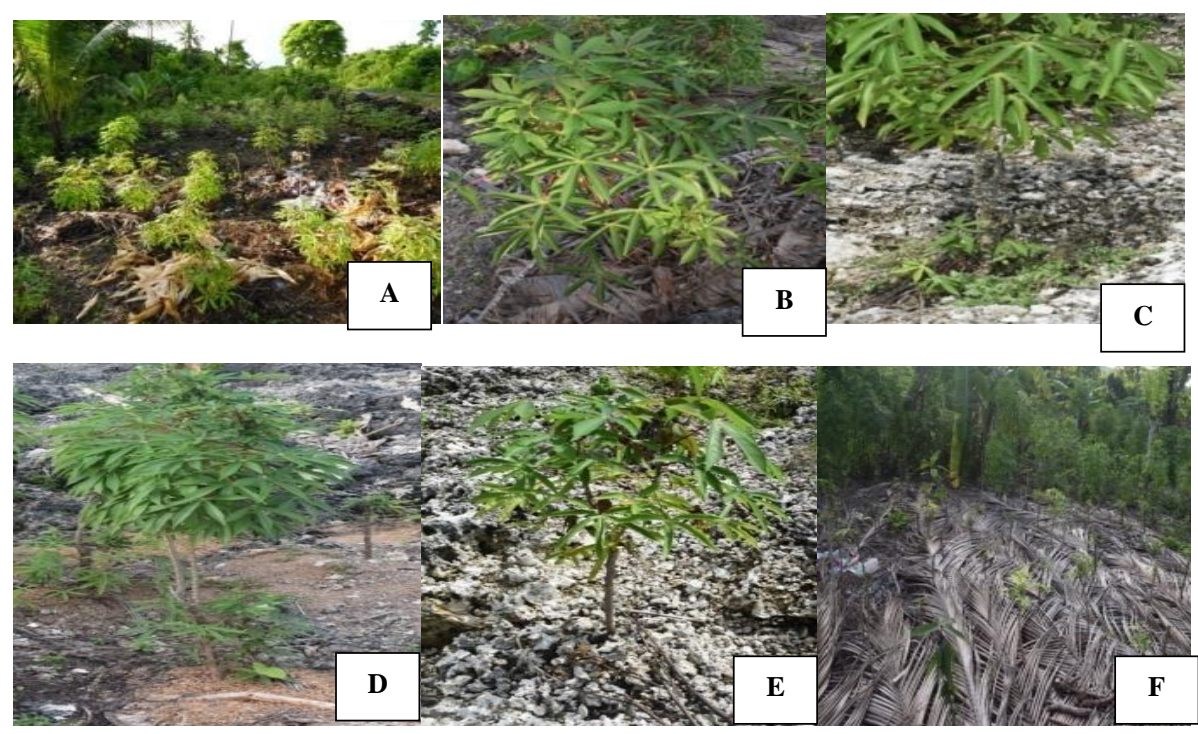

Fig.1. Sample of Heresoi materials to Cassava Plants

(A) Household waste/corn husk; (B) Plant litter; (C) Green Grass; (D) Sawdust: (E) Small size stone/gravel; and (F) Coconut Leaves

Picture 1. Show some material sources used by farmers on Wangi-Wangi Island in heresoi action. Picture 1 part A shows heresoi from household waste such as corn husks, fish bones and scales, tuber skinand fruits, leaves or twigs that are swept from trees around the house and others. Even those who carry household waste with those made from paper and plastic. This is also the case with figure 1. Parts B, C, and D, which each show heresoi action from plant litter (leaves of bananas or other dried plants); weeds or grass extracted from around plants; and sawdust. Picture Part E shows heresoi action by using small stones or gravel around the plants.

Physically, plants using heresoi from gravel less fertile than other ingredients. Despite this, the farmer learned of heresoi gravel is better than nothing. Rock Mulch is also used in certain places because of its potential to absorb heat during the day and release it at night [6]. 
Therefore, the use of rock mulch also has a positive influence on plant growth. It's different from heresoi's action in the pictures of parts A, B, C, D and E which are only carried out at the base of the roots of plants for each plant, heresoi action Picture part $\mathrm{F}$ is carried out in all areas of the plant with ingredients derived from coconut leaf canopy.

Based on results of this study is known that higher crop production in heresoi action with dry coconut skin material (Figure 1 part E) compared with heresoi using other ingredients. However, this heresoi action can only on agriculture land with a lot of soil and tends to be flat. Heresoi's action in Figure 1 parts A and B are mostly carried out by the community in a rocky area with a little soil, and the crop production is better than other heresoi actions ingredients. For this reason, the materials and forms of heresoi by farmer determined by the type of land; type of plant; and availability of raw heresoi materials.

In essence, Wangi-Wangi island farmer continue to do heresoi with ingredients adjusted to their availability. In fact, the type of material is not important for them, because the most important is plants get reso as efforts to restore natural materials that are no longer used by humans. For this reason, the heresoi materials type will be determined by the availability of reso during the farming activities, for example when harvesting corn, the heresoi activity will be dominated by corn husk material, or during the coconut harvest, heresoi will come from coconut leaves. The farmers believe that the technique of maintaining plants with heresoi action will fertilize the plants, so that these activities are always done by this map during the farming period.

Heresoi action when planting will continue until the period of plant maintenance and harvest. During the maintenance period, every time a farmer goes to a farming location and does weed cleaning activities, the weeds or grass that disturbs around the plant is extracted and then collected around the stem of the root plant. Farmers also often bring heresoi ingredients from their homes every time to the farming location using baskets or bags. When harvesting, parts of plants that are not used such as leaves and fruit peel will be used again as heresoi ingredients for subsequent plants And so on until it resembles a cycle.

The frequency of farmers to do heresoi's actions is also supported by their belief that the more heresoi diligently the more crops fertile and the more harvest production. This can be scientifically proven because based on the results of analysis of soil samples in 16 locations of the study area, it is known that the soil around the roots of plants with heresoi has more nutrient components than the soil without heresoi. Even organic matter from waste/dirt continues to experience weathering, so that the nutrient components become more complex over time. This situation justifies the statement of the farmers that with heresoi action make increasing crop production from time to time, because the development of nutrient complexity provides an increase in sustainable crop production.

In addition fertilizing plants and improving crop production in a sustainable manner, another benefit felt by farmers is to facilitate harvesting, especially in cassava plants (manihotutilisima, $s p$ ) and various other types of tubers. Heresoi action at the plant roots make soil around loose so as to facilitate the process of harvesting root crops, or in making land preparation for replanting.

\section{Assessing of Heresoi Action of Land Conservation Aspects}

Conservation is means preserving/preserving the carrying capacity, quality, function, and capability of the environment in a balanced manner [7] to ensure the wise and sustainable use of resources [8]. In this study, conservation interpreted as an effort to preserve agricultural 
land resources on Wangi-Wangi Island, so that it can provide agricultural products that are economically, socially and ecologically profitable. The intended effort is heresoi action in the management of agricultural crops, especially cassava plants which are the staple food of the local community.

Economically, heresoi can provide benefits in terms of fulfilling family food needs. Wangi-Wangi Island farmers carry out subsystem farming systems, the results of which are shown to meet the basic needs of the farmer's family by them self [9]. In the subsystem farming system, farm produce can be sold and the proceeds of the sale are used by farmers to meet their needs. From the most recognition of the informants in this study, it was found that they had never experienced difficulties in food because the farm produce was sufficiently available throughout the year. They planted several types of plants on one farm with an average land ownership of 0.82 hectares. The average amount of cassava production reached $11,494 \mathrm{~kg}$ ha-1, corn 2,893 kg ha-1, tuber1.095 kg ha-1, and seasonal horticulture plants with a production range according to the planting area. Cassava and corn have a selling price of IDR 8,000 to IDR 15,000 per $\mathrm{kg}$ depending on the variety.

From 83 informant farmers in this study, 79 of them had more than one farming location with a range of average distances between locations which were 0.1 to $1.8 \mathrm{~km} 2$. When the rainy season arrives, farmers can plant corn in monoculture on one land, and on the other land corn is intercropped with cassava, tuber and horticulture plants. Nevertheless, planting in intercropping/mixtures is mostly done by farmers because of the more varied availability of plants. In addition, the difference in planting time in the intercropping/mixture system allows the harvest time to be relatively different, so that it can maintain the stability of food stocks along the year.

Socially, heresoi action is a farming tradition of the Wangi-Wangi Island community that has been done since ancient times. Heresoi has become a local wisdom of the Wangi-Wangi Island community in the management of agricultural land, because it is a routine as well as a ritual or agriculture tradition. Wangi-Wangi Island farmers always done heresoi action every time go to farming location. Every time a farmer goes to the farming location, we will bring heresoi material to the location. When they are arrives at farm location, we will harvest plants that are ready to be harvested. After harvest, cassava stems are usually replanted, followed by cleaning the land. The results of land clearing in the form of grass or litter of plants will be placed around the plant roots as heresoi material. Likewise with harvested corn, and other horticultural plants, parts of plants that are not used, will be used as heresoi ingredients.

Observations at a number of points on the location of the study showed that almost no agricultural land was found that did not apply heresoi. Based on local knowledge, the community is aware that the problem of land resources that are dominated by rocks and low rainfall can only be overcome by applying the heresoi system. The system is believed to be able to have a positive influence on crop production, so that it continues to be maintained today. Local people tend to maintain their knowledge and local wisdom [10], because they believe that wisdom will provide the best lives [11].

Ecologically, Heresoi contains conservation aspects because it can preserve and balance the farming land ecosystem. The aspect of sustainability can be seen from the lack of implementation of shifting cultivation systems on the heresoi land. They generally focus on managing a number of farming locations, but are relatively immovable because of the land limited availability, and also they know that the farming location continuously being shaded is increasingly fertile. Some even suggested that their farming land was once rocky was now a land because it was often visited. This is a necessity because of the same function of heresoi as the mulching process, and also the weathering of heresoi material which will eventually 
form the soil. However, it should be acknowledged that some informants in this study sometimes left farming locations especially when they no longer heresoi intensely. They are not also aware that land protected will eventually become infertile, so it is sometimes abandoned for several planting seasons. Usually, they will return to managing the abandoned land by reopening it through the weli'a system.

Meanwhile, aspects of ecosystem balance can be achieved because heresoi annuls the recycling of waste, both from households and from farm locations. Through heresoi action, the waste is accelerated by the decomposition process by farmers and more quickly utilized by the land. The soil then forms nutrients which are ready to be presented for plant growth, which results will be enjoyed by humans later.

\section{Conclusion}

Based on the results of this study it can be concluded that the people of Wangi-Wangi Island carried out heresoi action in the management of agricultural land. Heresoi is an effort to add organic material around plant roots with the aim of fertilizing plants and increasing crop production in a sustainable manner. The organic material in question includes the results of waste or household waste such as land; sand; small pebbles; litter of garden plants; leftover processed sea products (fish fins and bones and shellfish), leftover processed products from food crops (corn husks and tubers); harvested canopy of plants around the farm site; termite house; sawdust; eggshell; charcoal and combustion ash. Furthermore, in terms of economic, social and cultural benefits, heresoi activities can fulfill the criteria for land conservation actions in the context of sustainable development. Economically, heresoi activities can increase crop production sustainably. Socially, heresoi activities can be one of the local wisdom of the community that shows the characteristics or tradition identity of the local community. Ecologically, heresoi activities can benefit the preservation and balance of agricultural land ecosystems.

\section{References}

[1]. BPS (Badan Pusat Statistik) Wakatobi Regency. Wakatobi Regency in Figure 2018. Catalog Number: 1101001.7407, Publication Number: 74070.1803., ISSN: 2088-7558. Wakatobi: Southeast Sulawesi, 2018.

[2]. Hadara. A. Ethnographic Tribes in Wakatobi. Mapan, Surabaya, 2014.

[3]. Suharta, N. Marginal Soil Characteristics and Problems of Sediment rock South in Kalimantan. Journal of Research and Development; 29 (4), 2010.

[4]. Aminuddin, A. M., Hidrawati., Usman Rianse, R. Marsuki I., dan Nur Arafah. Local Wisdom as Adaptation Strategy in Suboptimal Land Management at Binongko Island, Wakatobi Indonesia. Biosciences Biotechnology Research Asia, Vol. 14 (1), 129-136, March , 2017.

[5]. Puji Harsono. The Effects of Organic Mulches on Microclimate, Chemical Soil Properties and Performance of Red Chilli in Vertisol Soil in Sukoharjo at Dry Season. J. Hort. Indonesia 3(1):3541. April, 2012.

[6]. Reijntjes, C., Haverkort, B., dan Waters-Bayer, A. Agriculture Future: Introduction to Low External Input and Sustainable Agriculture. ILEIA. Translate by Y.Sukoco. Kanisius: Jakarta, 1999.

[7]. Maman Rahman. Value Conservation and Cultural Heritage. Indonesian Journal of Conservation (IJC) Vol. 1 No. 1, ISSN: 2252-9195page 30-39. Juni, 2012.

[8]. Indonesian National Encyclopedia. Conservation Concept. ISBN 979-9327-00-8 Volume 11. Delta Pamungkas: Jakarta, 2004.

[9]. NyomanYudiarini. Traditional Subsistent Agricultural Changes to Commercial Agriculture. dwijen AGRO Vol. 2 No. 1 ISSN : 1979-3901, Juni, 2014. 
[10]. Marfai, M.A. Introduction to Environmental Ethics and Local Wisdom. Gadjah Mada University Press, Yogyakarta, 2012.

[11]. Sunaryo, Joshi, L. The role of the Local Ecological Knowledge in Agroforestry Systems. The teaching materials 7. World Agroforestry Centre (ICRAF), Southeast Asia Regional Office, 2015. 